http://dx.doi.org/10.5800/GT-2014-5-3-0156

\title{
CAUSES AND CONSEQUENCES OF A CATASTROPHIC MUDFLOWS ON 28 JUNE 2014 NEAR ARSHAN VILLAGE IN THE REPUBLIC OF BURYATIA, RUSSIA
}

\author{
V. K. Laperdin, K. G. Levi, A. M. Lekhatinov, A. V. Kadetova, \\ V. A. Pellinen, A. A. Rybchenko
}

Institute of the Earth's Crust of SB RAS, Irkutsk, Russia

\begin{abstract}
On 28 June 2014, Arshan village and its heath resort facilities suffered from a shock descent of mudflows from Tunka Goltsy in the Republic of Buryatia, Russia. In this region, the last mudflow descent was recorded in 1971. The article provides an overview of the local natural environment of the site where the mudflows descended and the Kyngarga river flooding took place. Preliminary recommendations are given to ensure protection of the local population and regional infrastructure facilities from natural hazardous phenomena that are typical of sides of riftogenic basins located in the Baikal region.
\end{abstract}

Key words: mudflows, landslides, mudflow hazard, risks, processes, factors.

Recommended by S.I. Sherman

Citation: Laperdin V.K., Levi K.G., Lekhatiniv A.M., Kadetova A.V., Pellinen V.A., Rybchenko A.A. 2014. Causes and consequences of a catastrophic mudflows on 28 June 2014 near Arshan village in the Republic of Buryatia, Russia. Geodynamics \& Tectonophysics 5 (3), 799-816. doi:10.5800/GT-2014-5-3-0156.

\section{ПРИЧИНЫ И ПОСЛЕДСТВИЯ КАТАСТРОФИЧЕСКИХ СЕЛЕВЫХ ПОТОКОВ 28 ИЮНЯ 2014 Г. В ОКРЕСТНОСТЯХ ПОС. АРШАН, РЕСПУБЛИКА БУРЯТИЯ}

В. К. Лапердин, К. Г. Леви, А. М. Лехатинов, А. В. Кадетова, В. А. Пеллинен, А. А. Рыбченко

Институт земной коры СО РАН, Иркутск, Россия

Аннотация: 28 июня 2014 г. в пос. Аршан Тункинского аймака Республики Бурятия с каров Тункинских Гольцов произошел залповый сход селевых потоков, причинивших большой экономический ущерб этому курортному райо- 
V.K. Laperdin et al.: Causes and consequences of a catastrophic mudflows...

ну. Подобных явлений здесь не наблюдалось с 1971 г. Приводится краткий обзор природной ситуации в районе схода селей и паводка на р. Кынгарга и даются предварительные рекомендации по защите населения и региональной инфраструктуры от подобных опасных природных явлений, свойственных прибортовым частям рифтогенных впадин Байкальского региона.

Ключевые слова: грязекаменные потоки (сели), оползни, селевая опасность, риски, процессы, факторы.

Природа не знает остановки в своем движении и казнит всякую бездеятельность.

И. Гете

\section{1. ВВЕДЕНИЕ}

27-28 июня 2014 г. в окрестностях пос. Аршан Тункинского аймака Республики Бурятия произошло выпадение осадков большой интенсивности и, как следствие, в Тункинских Гольцах сформировались грязекаменные селевые потоки, а по руслу р. Кынгарга прошел паводок, что причинило большой экономический ущерб населению и отдыхающим. Подобных явлений здесь не наблюдалось с 1971 г., поэтому событие вызвало панику среди местного населения. 1 июля 2014 г. группа специалистов ИЗК СО РАН и Национального исследовательского Иркутского государственного технического университета выехала на место событий для предварительного изучения причин развития катастрофы. Уточним, что сель - периодически возникающий грязекаменный, водокаменный или водогрязекаменный поток. Генезис селей, возникающих в горах Кавказа, Средней Азии, Восточной и Западной Сибири, Сахалина и Камчатки, имеет свои характерные особенности. Мы не станем останавливаться на их различиях, но отметим, что на территории Восточной и Западной Сибири, покрытой лесом, довольно часто твердая составляющая селей насыщена деревьями до $30 \%$ от общей массы селевых отложений. Это является особенностью и определяет пульсирующий характер движения потоков по руслам и склонам гор и часто наносит повреждения мостовым переходам автомобильных и железных дорог и другим инженерным сооружениям (рис. 1).

\section{2. УСЛОВИЯ И ФАКТОРЫ ФОРМИРОВАНИЯ СЕЛЕЙ В РАЙОНЕ ПОС. АРШАН И ДОЛИНЕ Р. КЫНГАРГА}

Природная нестабильность - изменчивость окружающей среды во времени, приведшая к возникновению и сходу селевых потоков в пос. Аршан, бассейне р. Кынгарга и предгорном шлейфе Тункинских Гольцов, предопределена геолого-геоморфологическим строением и взаимодействием гидрометеорологического, гидрогеологического, сейсмотектонического факторов, которые выступают на разных участках территории высотных зон в разнообразных сочетаниях.

Геолого-геоморфологическая нестабильость. Геологической съемкой в стратиграфическом разрезе территории был выделен ряд комплексов коренных образований, верхний ярус которых сложен мраморами, часто брекчированными. Ниже мраморов залегает толща гнейсов и кристаллических сланцев, имеющих падение на юг под углами $30^{\circ}-70^{\circ}$ и определяющих развитие оползней-обвалов по напластованию коренных пород.

Гольцовая зона хребтов сложена разгнейсованными плагиогранитами и гнейсогранитами первой фазы китойского комплекса [Samburg, 1971]. Физико-механические свойства пород единого генетического комплекса во многом обусловлены особенностями залегания и тектонической раздробленности. По данным многолетних наблюдений установлено, что в зонах повышенной тектонической трещиноватости выветривание пород происходит в 2.0-2.5 раза быстрее по сравнению с их аналогами, находящимися вне зон разломов. В 4.7 раза увеличивается скорость разрушения рассланцованных пород, поставленных на «ребро», в отличие от их горизонтально залегающих аналогов. От разницы в скорости разрушения пород зависит мощность накопления продуктов выветривания и их гранулометрический состав, определяющие развитие разнообразных типов процессов, их количество и объемы. Установлено, что формирование конусов осыпей очагов твердой фазы селей - в большей мере происходит в местах выходов рассланцованных пород, в отличие от гранитоидных образований [Laperdin, 1985]. В то же время наблюдается обратная зависимость в формировании обвалов, образовавших в горной части русла Кынгарги многочисленные пороги, водопады, которые тяготеют к местам выходов магматических пород. Предгорная часть Тункинской котловины выполнена рыхлыми отложениями неоген-четвертичного возраста 

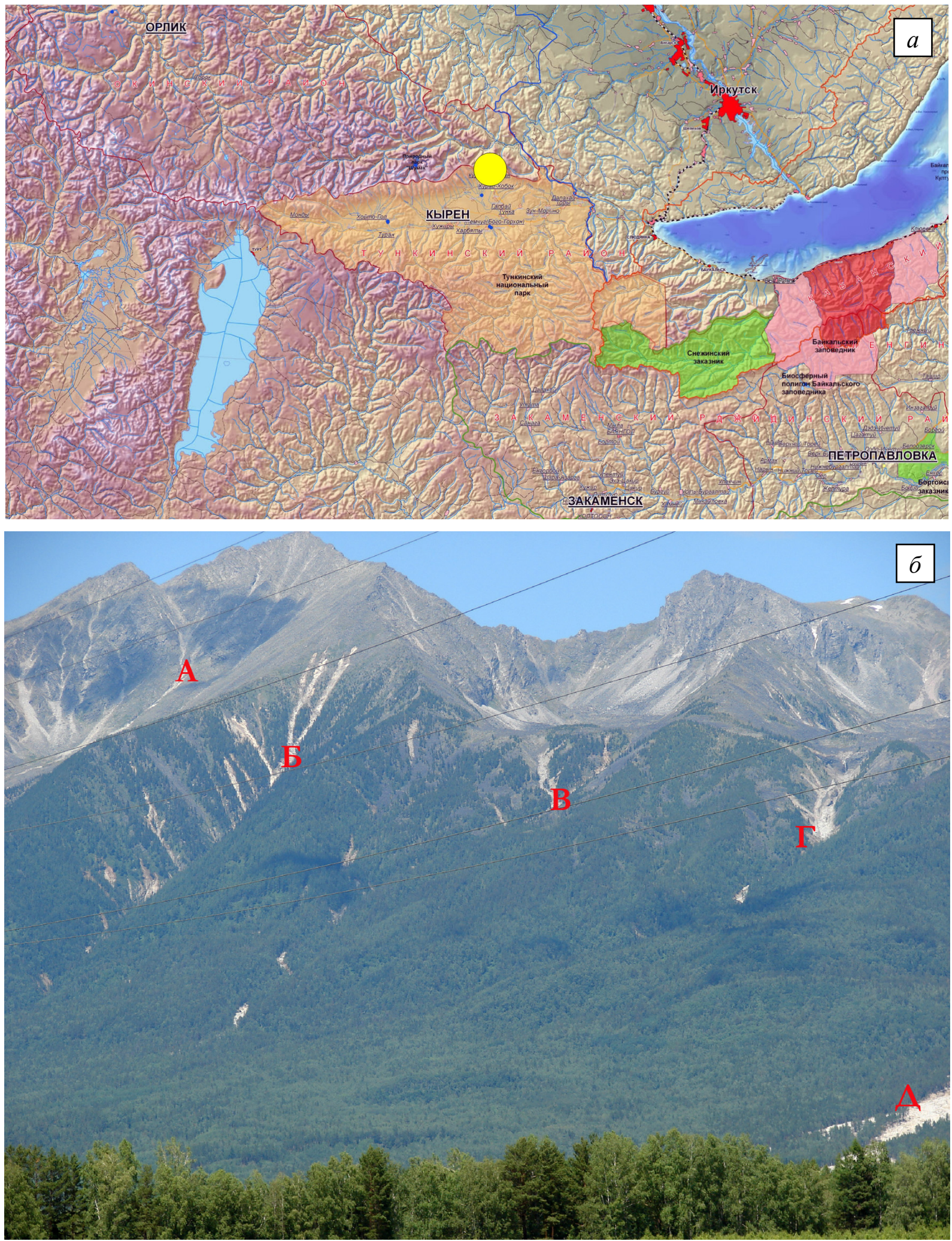

Рис. 1. $a$ - обзорная карта места событий 27-28 июня 2014 г. (желтый кружок) (фрагмент карты особо охраняемых территорий Республики Бурятии, цветные поля, см. оригинал на сайте - http://www.baikal-burpriroda.ru/files/ooptrb_new.jpg); б вид Тункинских Гольцов. Светлые прочесы в распадках - массовое проявление селевых потоков, оползней-сплывов и эрозии, определивших твердую составляющую селей. Слева направо - селеносные водотоки района п. Аршан: А - Безымянный, Б - 1-я Шихтолайка, В - Безымянный, Г - 2-я Шихтолайка, Д - Артемьева.

Fig. 1. $a$ - general map of the site where the disaster took place on 27-28 June 2014 (yellow circle) (a fragment of the map of protected natural areas in the Republic of Buryatia, http://www.baikal-burpriroda.ru/files/ooptrb_new.jpg); $\sigma$ - Tunka Goltsy. Light colours - massive mudflows, landslide, slip-out and erosional soils that comprised the mudflows. Left to right - water streams that carried mudflows near Arshan village: A - Bezymyanny, Б - 1st Shikhtolaika, B - Bezymyanny, $Г$ - 2nd Shikhtolaika, Д - Artemieva. 


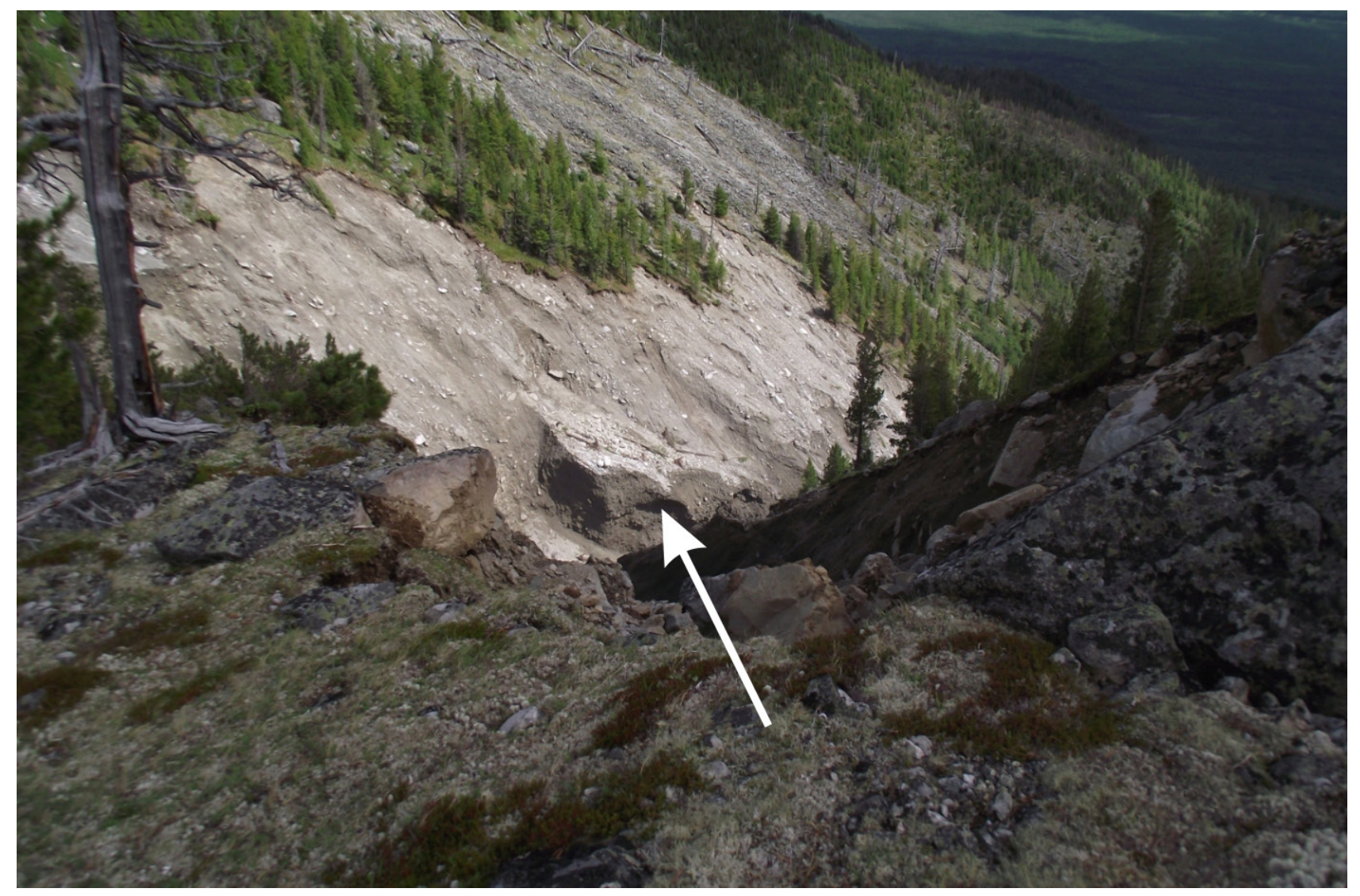

Рис. 2. Оползень-сплыв в левом борту Шихтолайки.

На первом плане - граница отрыва конечной морены, которая перегораживает выход из кара. На втором плане - фрагмент срыва только что оттаявшего слоя осыпного материала. Об этом свидетельствует остаток вскрытого промороженного блока грунта (стрелка), имеющего резкие, отвесные формы.

Fig. 2. Landslide at the left side of Shikhtolaika.

Front - the separation edge of the terminal moraine that blocks the kar's outlet. Background - a fragment of detachment of the just-melted layer of loose material. It is evidenced by an outcrop of the remaining block of frozen soil (arrow) which has sharp and steep edges.

и представлена аллювиально-делювиальными, пролювиальными, ледниковыми, но преимущественно флювиогляциальными отложениями, продуктами выветривания и денудации метаморфических и изверженных пород, отражающих состав образований коренной основы, слагающих горные сооружения Тункинских Гольцов. Отложения предгорного шлейфа обладают весьма высокими фильтрационными свойствами, в связи с чем в полосе сопряжения гор и впадины интенсивно гасится поверхностный сток и практически все ручьи, выходящие из каров, не имеют постоянного поверхностного стока.

Для ледниковых отложений характерна различная, но относительно высокая концентрация глинистых включений, понижающих, за счет пучинистости, сжимаемости и просадочности, модуль деформации до 70

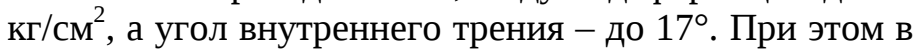
ледниковых отложениях за счет глинистых включений повышаются коэффициенты пластичности, пористости (0.65) и угла естественного откоса $\left(10^{\circ}\right)$, определяю- щие несущую способность переувлажненных и сорвавшихся со склона грунтов, как это произошло 28 июня в месте выхода из ледниковых каров ручьев Первой и Второй Шихтолайки (рис. 2).

Рыхлые отложения, слагающие русло, пойму и террасы р. Кынгарга и предгорного шлейфа, представлены разноокатанными валунами, галькой и разнозернистыми песками. При выходе реки из гор и по мере удаления от их подножья размерность валунов в русле заметно уменьшается. А на расстоянии полутора-двух километров основным компонентом отложений становится галька, дресва, песок и глинистые отложения, хотя встречаются и валунные включения в виде фрагментарных инъекций - результаты залповых выносов селей, определяющие энергетику потоков в различные периоды их формирования. 27-28 июня во время паводка на р. Кынгарга объем водной составляющей, по сравнению с паводком 1971 г., был значительно ниже и площадь сечения максимального уровня воды составляла $54.9 \mathrm{~m}^{2}$. 

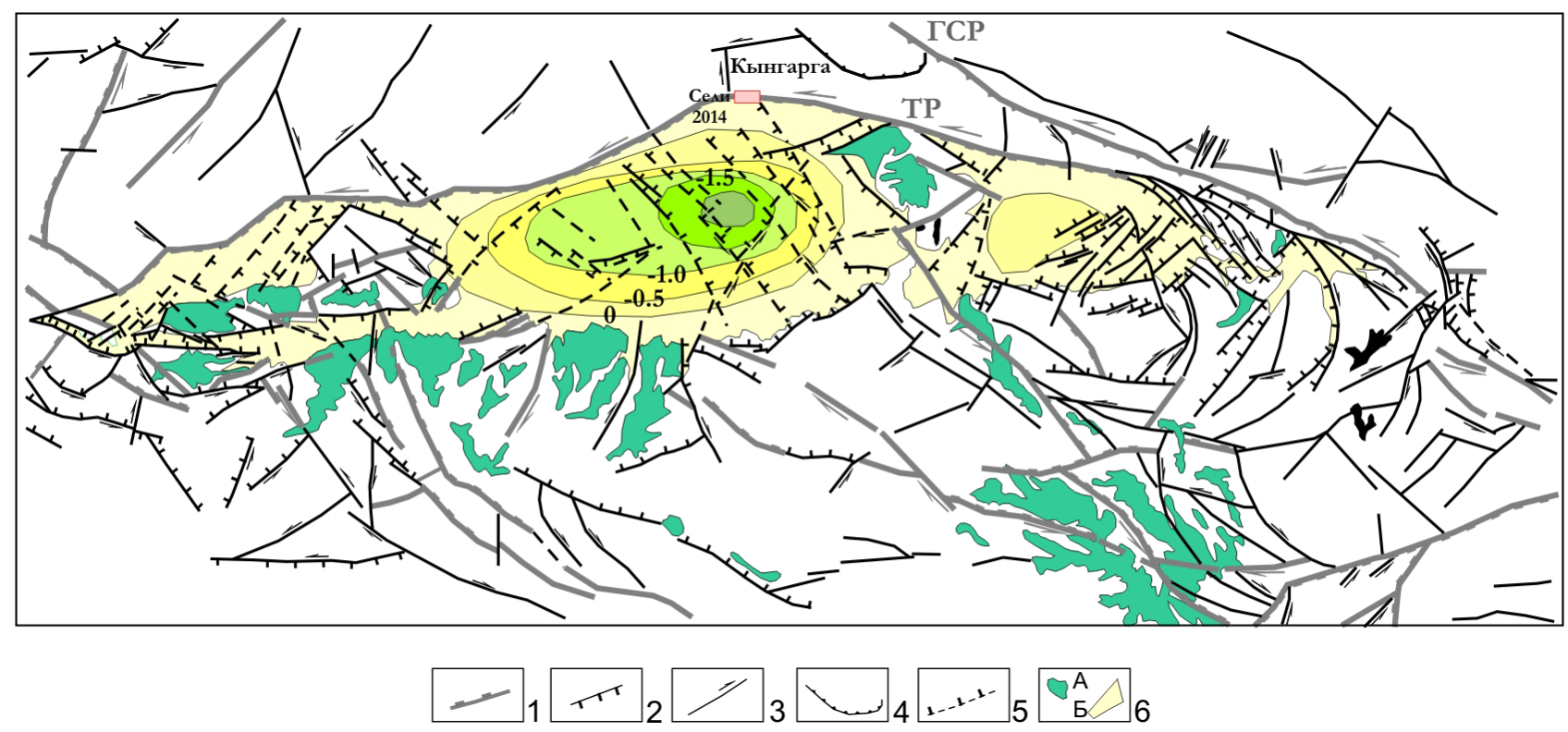

Рис. 3. Активные разломы Тункинской рифтогенной впадины (Юго-Западное Прибайкалье).

1 - активные разломы с известной толщиной зон тектонитов; 2 - сбросы; 3 - сдвиги; 4 - взбросы и надвиги; 5 - предполагаемые зоны разломов; 6 - базальтовые покровы и потоки (А) и осадки рифтогенных впадин (изопахиты в километрах от уровня моря) и речных долин (Б); ГСР - Главный Саянский разлом; ТР - Тункинский разлом.

Fig. 3. Active faults in the Tunka riftogenic basin, South-Western Pribaikalie.

1 - active faults with known thickness of zones of tectonites; 2 - normal fault; 3 - strike-slip faults; 4 - reverse faults and thrusts; 5 - assumed fault zones; 6 - basalt nappes and flows (A) and sediments of riftogenic basins (isopachytes in kilometres from the sea level) and river valleys (Б); ГСР - Main Sayan fault; TP - Tunka fault.

Эндогеодинамическая нестабильность. Сейсмичность территории и интенсивные осадки могут являться основными причинами развития подобных чрезвычайных ситуаций. В ночь с 27 на 28 июня, по данным сейсмостанции «Аршан» БФ ГС СО РАН, ощутимых сейсмических событий не зафиксировано.

Геолого-структурные образования бассейна р. Кынгарга сформировались в ходе длительных тектонических деформаций, сопровождавшихся воздыманием и опусканием различных по размеру тектонических блоков земной коры, проявившихся в процессе развития Байкальского рифта. Морфология Тункинских Гольцов определяется двумя генеральными разломами Тункинским и Главным Саянским и серией региональных и локальных разломов, формирующих различные по размерам тектонические блоки [Levi et al., 2012]. Эту ситуацию отражает рис. 3.

Тункинский разлом ограничивает горную систему Тункинских Гольцов с юга и контролирует положение цепи котловин Тункинской рифтогенной впадины, а Главный Саянский разлом ограничивает Тункинские Гольцы с северо-востока. По одному из разломов субмеридионального направления по линии Аршан Улан-Горхон заложена долина-ущелье р. Кынгарга, имеющая более глубокий врез по сравнению с долинами, расположенными к востоку и западу. К сопряжению разлома р. Кынгарга с Тункинским разломом приурочена разгрузка углекислых минеральных лечебных вод (левый борт р. Кынгарга) на северной окраине пос. Аршан. Напряженно-деформированное состояние земной коры контролирует направленность и амплитуды горизонтальных и вертикальных перемещений тектонических блоков. Надо отметить, что рн пос. Аршан не отличается высокой сейсмической активностью (рис. 4) и характеризуется землетрясениями с энергетическим классом $\leq 10$. Однако так было не всегда. Свидетельством возникновения здесь мощных сейсмических событий является сбросо-сдвиг Аршанской палеосейсмодислокации, время ее последнего обновления оценивается 1024-1341 гг. ВР, а следы более ранних событий датируются 6733-7867 и 921412724 гг. ВР [Smekalin, 2000]. Исходя из сказанного, можно сделать вывод, что сейсмичность играет лишь второстепенную роль в подготовке материала для формирования селей и развития оползневых процессов, тогда как исключительная - принадлежит климатическим факторам.

При активизации сейсмических событий в бассейне р. Кынгарга не исключен вариант каскадного развития экзогеодинамических процессов. Сейсмическая инициация селеобразования может происходить в случае совпадения по времени землетрясений с периодами ливневых дождей или активного снеготаяния, а на склонах долины р. Кынгарга могут формиро- 


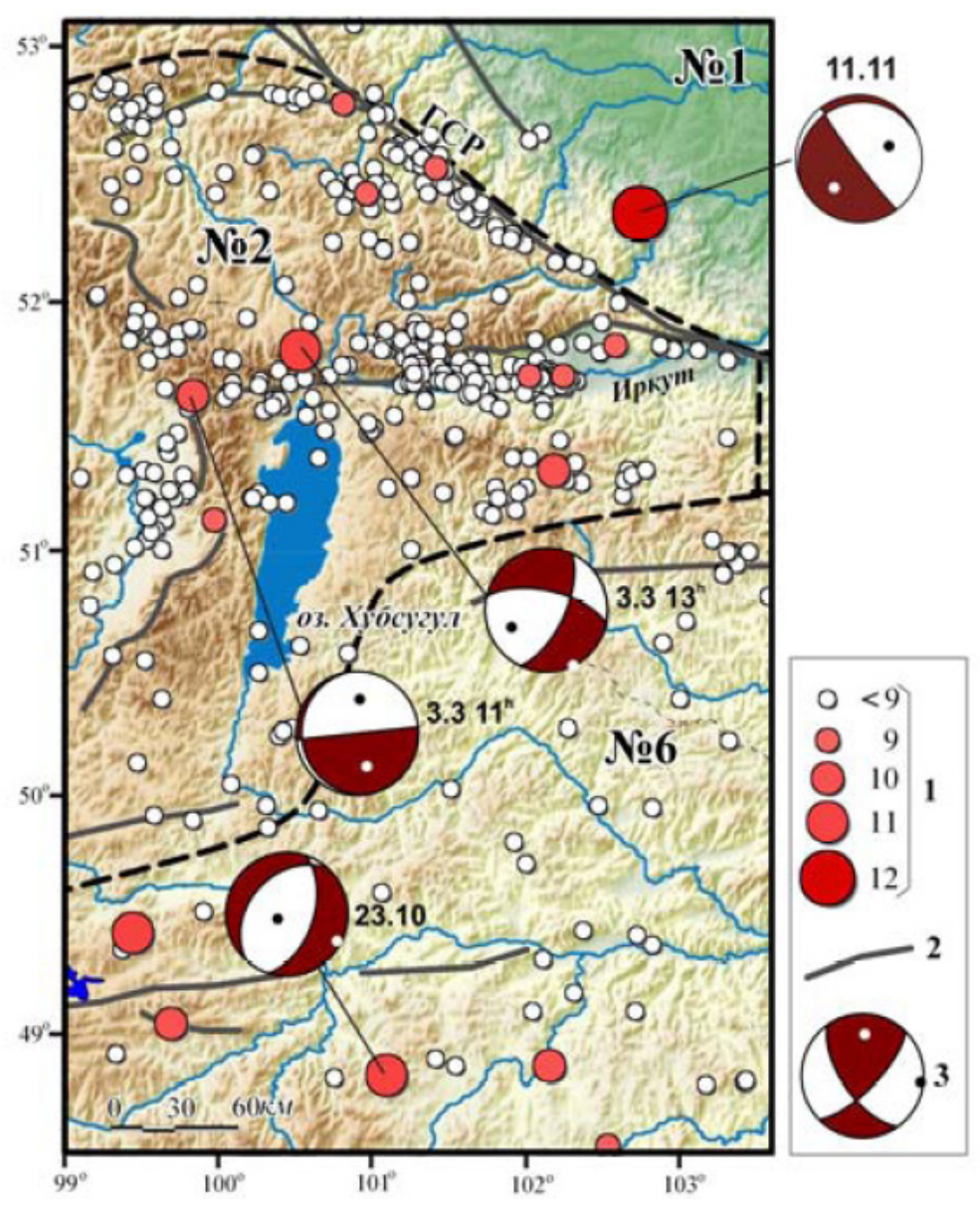

Рис. 4. Карта эпицентров землетрясений Хубсугул-Тункинского (№ 2) и частично Западно-Забайкальского (№ 6) района в 2007 г.

1 - энергетический класс $K_{p} ; 2$ - кайнозойский разлом; 3 - стереограмма механизма очага землетрясения в проекции нижней полусферы; цифрами указана дата (число, месяц) землетрясения; ГСР - Главный Саянский разлом [Melnikova et al., 2007].

Fig. 4. The map showing epicentres of earthquake that took place in Khubsugul-Tunka (No. 2) and partially West Transbaikalia (No. 6) regions in 2007.

1 - energy class, $K_{R} ; 2$ - Cenozoic fault; 3 - stereogram of earthquake focal mechanism in the projection of the lower hemisphere; numbers show dates (date, month) when earthquakes occurred; ГСР - Major Sayan fault [Melnikova et al., 2007].

ваться оползни-сплывы рыхлых грунтов объемом до 30 тыс. $\mathrm{M}^{3}$.

В целом сейсмотектоническая активность в регионе, в сочетании с климатическими и геоморфологическими факторами, определяет сложность строительства и эксплуатации инженерных сооружений. Все сказанное в совокупности значительно повышает уязвимость территории и сопровождается увеличением уровня социального и экономического рисков. В таких районах должны проводиться оценки инженерногеологических условий территории и мониторинг опасных природных процессов с целью повышения уровня надежности различного рода сооружений, выполнения мероприятий по селезащите и снижения риска от схода селей и оползней в горных долинах, подобных долине р. Кынгарга и во всей предгорной части Тункинских Гольцов и на хр. Хамар-Дабан.

\section{3. ОБЪЕКТИВНАЯ ПРИРОДНО-СОЦИАЛЬНАЯ СИТУАЦИЯ В ПОС. АРШАН И ДОЛИНЕ Р. КЫНГАРГА}

Институт земной коры СО РАН постоянно уделяет внимание опасным экзогеодинамическим явлениям в зоне Байкальского рифта. Одной из первых публикаций по результатам изучения последствий селевого паводка в г. Слюдянке, произошедшего 20 июня 1960 г., явилась коллективная монография [Solonenko, 1963]. Сход селевых потоков в этом районе повторился в 1971 и 1973 гг. Временная динамика схода селевых потоков в Юго-Западном Прибайкалье приведена на (рис. 5) [Levi, Zadonina, 2013]. Фурье-анализ данных показывает, что сход селевых потоков на территории Юго-Западного Прибайкалья в среднем происходит с периодами продолжительностью 22, 11, 7, 4.0-2.5 лет. 


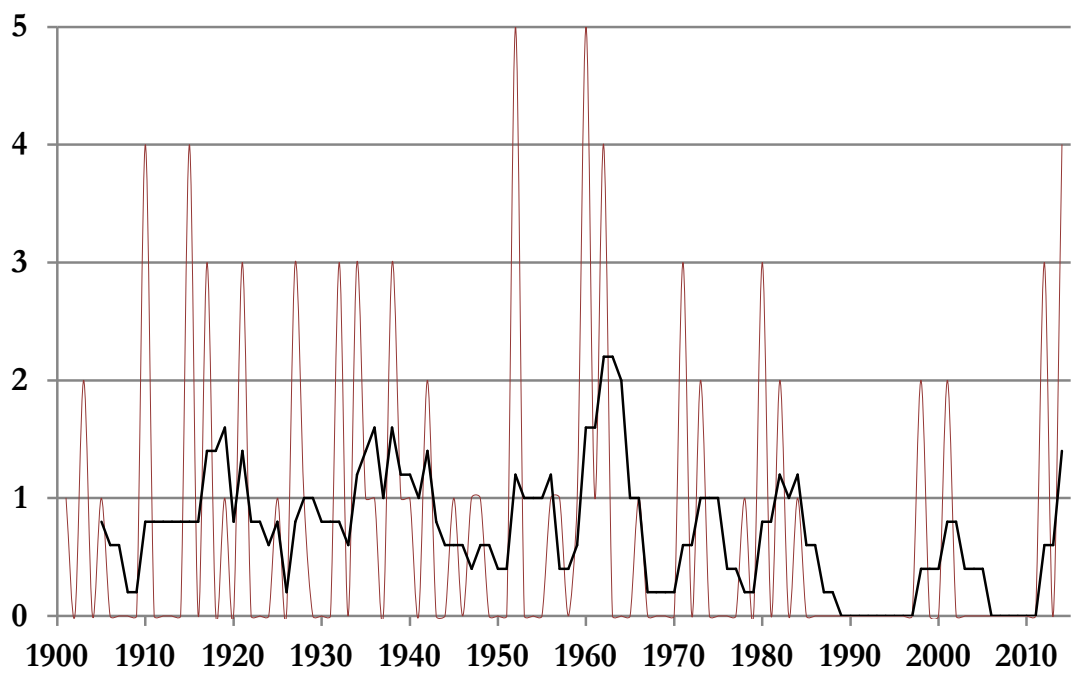

Рис. 5. Динамика схода селевых потоков в Юго-Западном Прибайкалье с 1901 по 2014 г. (черная кривая - сглаженные 5летним окном исходные данные).

Fig. 5. The dynamics of mudflows in the South-Western Pribaikalie from 1901 to 2014. The black curve shows five-year levelled input data.

Приводимые здесь результаты обследования показали, что в ночь с 27 на 28 июня 2014 г. в результате локального выпадения интенсивных осадков (50 мм и более) в Тункинских Гольцах с нижних уступов ледниковых каров практически одновременно сошло семь селевых потоков (рис. 6). Установлено, что селевые потоки, сошедшие по падям ручьев Безымянный и Вторая Шихтолайка, соединились в средней части склона в один, который и достиг пос. Аршан. На своем пути сель разрушил около трех десятков домов, санаторий, лицей для одаренных детей и другие постройки, погибла женщина. Одновременно на р. Кынгарга сформировался паводок, разрушивший два моста и пекарню; слоем песка (10-50 см) занесло активно посещаемую территорию и лечебные корпуса курорта, а также торговые и развлекательные строения, расположенные на пойме и низкой террасе на территории курорта и за ее пределами (рис. 6).

Разрушительный селевой поток 28 июня 2014 г. имел следующие параметры:

- площадь конуса выноса, сложенного в верхней, предгорной, части склона (уклон которого находится в пределах $8^{\circ}-10^{\circ}$ ) крупноглыбовым материалом, в средней и нижней его частях (уклон $3^{\circ}-8^{\circ}$ ) - крупноглыбовыми обломками и стволами деревьев, внедренными в суглинисто-супесчаную массу, составляет $171378.38 \mathrm{~m}^{2}$; $4.5 \mathrm{M}$

- мощность селевых отложений местами не менее

- объем вынесенного и отложенного крупноглыбового материала, ограниченного конусом выноса находится в пределах 771000 м³ $^{3}$ Большая, приблизительно в два раза, масса материала вынесена и отложена ниже по склону в виде глинисто-супесчаных наносов, мощностью от 10 до 50 см и больше, покрывших сотни гектаров лесного массива.

Вся инфраструктура пос. Аршан располагается в узкой прибрежной полосе р. Кынгарга и на предгорном шлейфе Тункинских Гольцов. Предгорный шлейф представляет собой слившиеся воедино древние конусы залповых и локальных выносов селей в Тункинскую котловину и является зоной повышенной опасности и риска возникновения чрезвычайных ситуаций. Для обжитой территории наибольшую угрозу в предгорной заселенной части территории представляют паводки и водогрязекаменные потоки, плотность которых по результатам прошлых обследований достигает 2500 кг/м³, а по р. Кынгарга - наносоводные сели плотностью до 1600 кг/м³ . В горах опасными процессами являются каменные обвалы, оползни коренных пород, оползни-сплывы в рыхлых отложениях, снежные и каменные лавины. Угроза опасности от перечисленных процессов в связи с неконтролируемым освоением территории повышается с каждым годом. Отметим, что с 1971 г. по 2014 г. проявления селей здесь не наблюдались. Вследствие длительного отсутствия селевых потоков и паводков селеопасные площади прибрежной зоны р. Кынгарга и предгорного шлейфа освоены или стихийно осваиваются. В основном это гражданское строительство (коттеджи, дома, дачи), которое ведется на площадях высочайшего риска (рис. 7).

Реальная и перспективная оценка степени опасности и риска существующей инфраструктуры пос. Аршан может быть получена при осуществлении мониторинга повторяемости периодически возникающих 


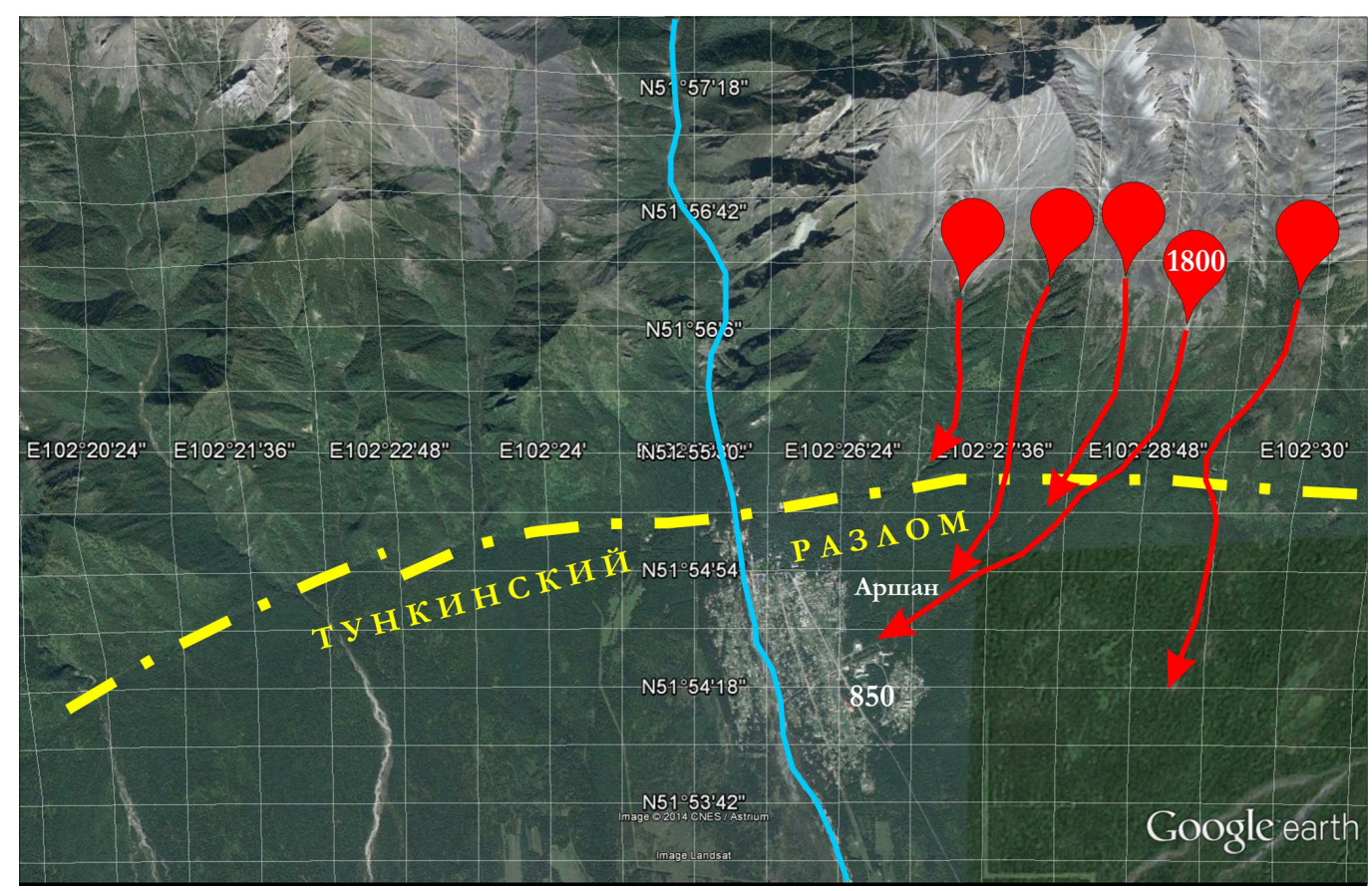

Рис. 6. Схема схода грязекаменных и грязевых потоков (селей) с Тункинских Гольцов (красные стрелки) и паводка на р. Кынгарга (голубая линия) 28 июня 2014 г.

Цифры 1800 и 850 - перепад абсолютных высот каров и нижнего края остановки крупноглыбового материала. Желтым штрих-пунктиром показан Тункинский разлом.

Fig. 6. A scheme of mud-and-stone flows from Tunka Goltsy (red arrows) and the Kyngarga river flooding (blue line) on 28 June 2014.

1800 и 850 - differential of absolute elevations of kars and the lower border where large-block mudflows stopped. Yellow dotted line - Tunka fault.

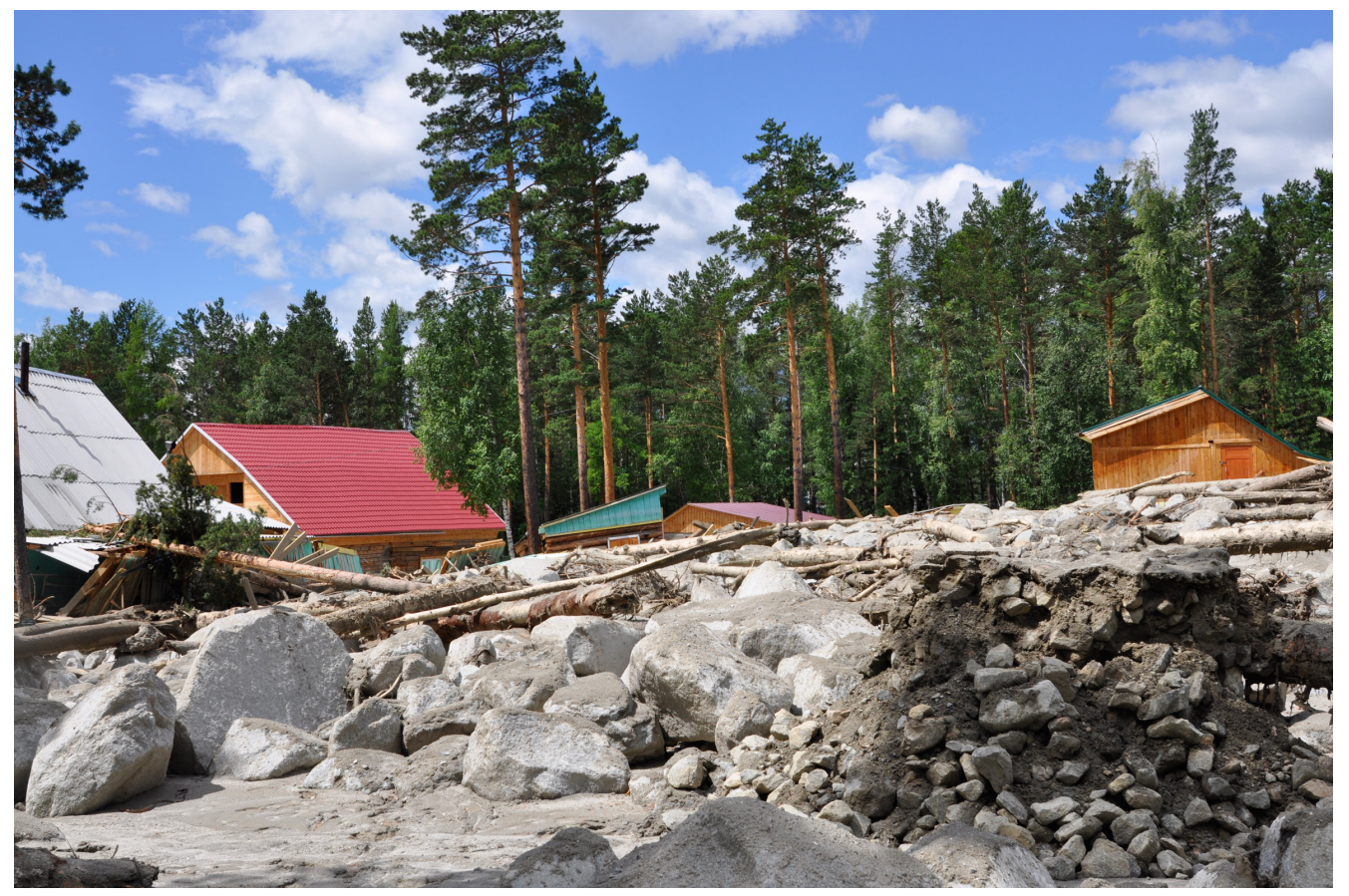

Рис. 7. Масса крупноглыбового материала, «поглотившая» несколько домов и лесной массив и остановившаяся на восточной окраине пос. Аршан.

Fig. 7. The mudflow containing large rock blocks flooded several houses and a forest and stopped in the eastern outskirts of Arshan village. 
сейсмических событий и количества выпадения атмосферных осадков высокой интенсивности, особенно в высокогорной зоне.

Гидрометеорологическая и инженерно-геологическая нестабильность. К сожалению, из-за отсутствия метеостанции в пос. Аршан не было зафиксировано количество выпавших осадков, ставших первопричиной формирования водогрязекаменных, перемешанных с древесной растительностью, селевых потоков, сошедших из ледниковых каров, расположенных в высокогорной зоне Тункинских Гольцов. Наиболее вероятно смещение горного материала на склонах именно во время таяния снега или выпадения интенсивных дождей, которые и следует считать инициаторами возможных чрезвычайных ситуаций, подтверждениями подобных явлений служат гравитационные обвалы и оползни-сплывы.

Согласно нивелированию поперечного профиля русла по меткам высокой воды величина расхода потока в р. Кынгарга во время паводка 27-28 июня составила $10.8 \mathrm{~m}^{3} / \mathrm{c}$, скорость потока составляла 5.07.0 м/с. По наблюдениям прошлых лет повторяемость водокаменных селей на p. Кынгарга, плотностью $1100-1600 \mathrm{kг} / \mathrm{M}^{3}$, составляет раз в 20-40 лет или более [Solonenko, 1963]. Во время формирования и прохождения селей и паводков наблюдаются изменения русла и значительное разрушение берегов реки. Например, во время паводка 27-28 июня 2014 г. вовлечение лесной растительности, смытой с берегов и островов р. Кынгарга в водоток, привело к закупорке проемов мостов и, как следствие, их разрушению. За время прохождения паводка расход воднокаменной массы, перемешанной со стволами деревьев, составил $10 \mathrm{~m}^{3} / \mathrm{c}$, а объем грязекаменного материала, с валунами диаметром 0.2-0.7 м, достиг 16 тыс. м ${ }^{3}$. Отметим, что наиболее ущербным для инфраструктуры пос. Аршан и объектов санатория оказался сель, прошедший в третьей декаде июля 1971 г. (рис. 8) [Budz, Astrakhantsev, 1968].

Во время паводка 27-28 июня, запруживая валунами и деревьями русло, водокаменный поток малой консистенции в пределах поселка создал условия для формирования новых русел, привел к некоторым разрушениям инфраструктуры. На различных участках бассейна р. Кынгарга имеются зоны риска, которые следует выделить и обозначить предупреждающими знаками для многочисленных туристов и отдыхающих. Границы этих зон могут быть установлены с учетом поражения территории селями, оползнями-сплывами, обвалами, каменными и снежными лавинами, формирование которых происходит в результате выпадения аномального количества осадков (с суточным максимумом до 150 мм) и слабых землетрясений. По данным наблюдений на метеостанции «Аршан», при сходе селевых потоков количество выпадавших атмосферных осадков в бассейне р. Кынгарга за 8-10 часов достигало 50-80 мм. Это количество осадков за дожд- ливый период в этом районе может являться основой для прогноза возможного формирования селевых и водных паводков, оползней-сплывов, обвалов, приводящих к развитию чрезвычайных ситуаций.

Крутопадающие, до вертикального залегания, пласты метаморфических пород, наличие большого количества трещин напластования и сейсмотектонических дислокаций определили развитие хорошо выраженных на поверхности гор «занозистых» форм рельефа. «Занозистость» способствует процессу фильтрации поверхностного стока на уровень грунтовых вод и пополнению подземного стока, принимающего участие в формировании водной составляющей селей [Laperdin, Kachura, 2010].

Следует отметить, что пути движения пресных и даже минеральных вод в аллювиальных отложениях долины р. Кынгарга весьма уязвимы и чувствительны к воздействию паводков и селей, что приводит к разрушению каналов выхода водотоков к очагам разгрузки [Vasilievsky, Tolstikhin, 1930].

\section{4. ЗАКЛЮЧЕНИЕ И НЕКОТОРЫЕ РЕКОМЕНДАЦИИ ПО СЕЛЕЗАЩИТЕ}

Результаты проведенных исследований по оценке последствий схода селей со склонов Тункинских Гольцов и паводка по р. Кынгарга позволяют выделить опасные, потенциально опасные и неопасные участки на освоенной и осваиваемых территориях пос. Аршан и его окрестностей.

Территория, занятая пос. Аршан, находится в зоне, где по макросейсмическим и инструментальным данным потенциальная сейсмичность Тункинского и Саянского разломов оценивается в 9-10 баллов.

Важнейшими элементами опасности и риска в пределах территории бассейна р. Кынгарга являются экзогенные геологические процессы, развивающиеся в специфических условиях и обладающие различным геодинамическим потенциалом.

Наибольшую опасность в горах представляют сели, обвалы, оползни коренных пород и оползни-сплывы, каменные и снежные лавины. Проявление опасных процессов происходит периодически и связано с высокой «энергией» рельефа, выпадением большого количества осадков и сейсмической активностью территории.

Последствия схода селей и паводка на р. Кынгарга могли быть в разы больше даже при выпадении такого же количества осадков, случись это в конце июля или в августе, когда грунты в селевых очагах максимально оттаивают от сезонной мерзлоты. В данном случае, по многолетним наблюдениям, в подобных условиях грунты оттаяли на 50, максимум $70 \mathrm{~cm}$, а промерзают они на 120-150 см, то есть большая часть грунтов, способных сорваться со склонов, осталась на месте (см. рис. 2). Но если подобное произойдет повторно, то 


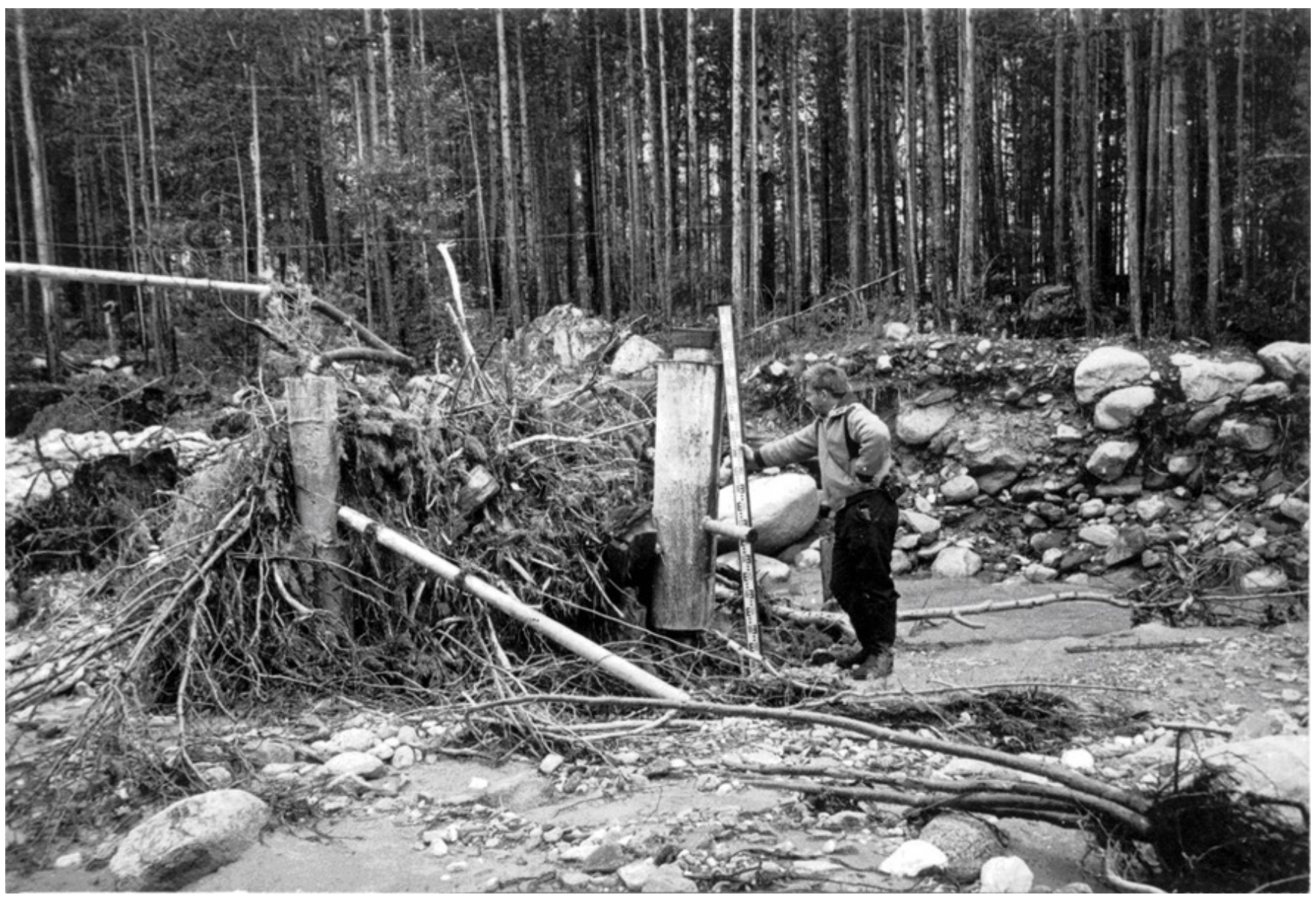

Рис. 8. Последствия схода селевого потока по долине р. Кынгарга в июле 1971 г. и разрушение скважин на минеральных источниках.

I Fig. 8. The site after mudflow descent along the Kyngarga river in July 1971 and damaged mineral water wells.

отложенный крупноглыбовый материал в виде конуса выноса поглотит грязь и воду, а глыбы, лишившись основы движения «смазки», потеряют скорость и остановятся, не доходя до поселка.

В целях предотвращения подобных событий авторы рекомендуют:

- прежде чем приступать к строительству инженерных сооружений, необходимо проводить детальные, целенаправленные инженерно-геологические и гидрогеологические изыскания;

- необходимо составить карту районирования селеопасности бассейна р. Иркут, с выделением опасных, потенциально опасных и безопасных территорий;

- для разработки мероприятий по инженерной защите проектируемых объектов, с учетом возможного негативного влияния предполагаемых сооружений на подземные минеральные лечебные источники АршанТункинского месторождения, необходимо отнести их к объектам режима первого пояса охранной зоны [Laperdin et al., 2010].

Следует подчеркнуть, что в настоящее время в особо опасной зоне находятся санаторные корпуса пос.
Аршан, жилые дома и другие строения. Они расположены в пределах поймы и надпойменной террасы р. Кынгарга и во время селевых и водных паводков могут быть разрушены. Возведение защитных сооружений от селей и паводков для отдельных объектов нецелесообразно. Наиболее надежным средством защиты является сооружение железобетонных желобов, обеспечивающих свободный и контролируемый сброс селевой массы за пределы пос. Аршан.

Фактически во всех известных случаях разрушительная сила водных паводков и селей выражается в их поражающей способности, от которой страдают, прежде всего, присклоновые и прибрежные зоны. К сожалению, активное освоение поймы и низких террас в настоящий период происходит без учета опасных процессов и без возведения защитных сооружений. Ведь только благодаря относительно малой заселенности территорий грязекаменные сели практически впервые нанесли экономический ущерб. Проявление паводков в р-не пос. Аршан и их негативное воздействие на хозяйственную деятельность осуществляются, главным образом, в форме водной боковой и глубин- 
ной эрозии, переноса и аккумуляции глыбового материала. В результате подвергаются опасности либо разрушаются объекты хозяйственного назначения, скважины для добычи воды, изменяются дебиты минеральных источников.

Предгорная часть территории, сложенная мощной толщей аллювиально-делювиально-флювиогляциальных отложений, обладающих свойствами отличного дренажа, легко гасит поверхностный сток, а отсутствие заболоченных земель делает такие участки наиболее благоприятными для застройки, но с обяза- тельной организацией надежной превентивной защиты.

Инженерно-геологическую оценку территории следует рассматривать как предварительную, которую при определении конкретных технических условий необходимо наполнить требованиями регламентирующих документов. Сход селевых потоков в пос. Аршан 28 июня 2014 г. может быть примером природных катаклизмов, которые необходимо учитывать при выборе и оценке площадок по степени опасности для строительства любых инженерных сооружений.

\section{5. ЛИТЕРАТУРА / REFERENCES}

Budz M.D., Astrakhantsev V.I., 1968. Mudslides. In: Engineering geology of Pribaikalie. Nauka, Moscow, p. 108-111 (in Russian) [Будз М.Д., Астраханцев В.И. Сели // Инженерная геология Прибайкалья. М.: Наука, 1968. С. 108-111].

Laperdin V.K., 1985. On the issue of morpholithogenesis and denudation in the periglacial belt in the southern East Siberia. Geografiya i Prirodnye Resursy (Geography and Natural Resources) (1), 53-61 (in Russian) [Лапердин В.К. К вопросу морфолитогенеза и денудации в перигляциальном поясе юга Восточной Сибири // География и природные ресурсы. 1985. № 1. С. 53-61].

Laperdin V.K., Kachura R.A., 2010. Geodynamics of Hazardous Processes in Zones of Natural and Technogenic complexes in East Siberia. IEC SB RAS, Irkutsk, 312 p. (in Russian) Лапердин В.К., Качура Р.А. Геодинамика опасных процессов в зонах природно-техногенных комплексов Восточной Сибири. Иркутск: ИЗК СО РАН, 2010. 312 с.].

Laperdin V.K., Kustov Yu.I., Kachura R.A., 2010. The factors of natural instability and technogenic risks in the territory of Arshan Spa (Kyngarga river basin, Republic of Buryatia). Zashchita okruzhayushchey sredy v neftegazovom komplekse (Protection of Natural Environment in Oil and Gas Complex) (4), 37-45 (in Russian) [Лапердин В.К., Кустов Ю.И., Качура Р.А. Факторы природной нестабильности и техногенных рисков на территории курорта Аршан (бассейн р. Кынгарга, Республика Бурятия) // Защита окружающей среды в нефтегазовом комплексе. 2010. № 4. С. 37-45].

Levi K.G., Zadonina N.V., 2013. Heliodynamics: Natural Aspects of Global Solar Minimums. Vol. 1, Book 4. Publishing House of the Irkutsk State University, Irkutsk, 607 p. (in Russian) [Леви К.Г., Задонина Н.В. Гелиогеодинамика: Природные аспекты глобальных солнечных минимумов. Т. 1, кн. 4. Иркутск: Изд-во ИГУ, 2013. 607 с.].

Levi K.G., Zadonina N.V., Yazev S.A., Voronin V.I., 2012. Recent Geodynamics and Heliogeodynamics. Textbook. Publishing House of the Irkutsk State University, Irkutsk, 539 р. (in Russian) [Леви К.Г., Задонина Н.В., Язев С.А., Воронин B.И. Современная геодинамика и гелиогеодинамика: учебное пособие. Иркутск: Изд-во ИГУ, 2012. 539 с.].

Melnikova V.I., Gileva N.A., Masalsky O.K., 2007. Pribaikalie and Transbaikalia. Irkutsk, 2007. http://www.seis-bykl.ru (in Russian) [Мельникова В.И., Гилева Н.А., Масальский О.К. Прибайкалье и Забайкалье. Иркутск, 2007. Электронный ресурс: http://www.seis-bykl.ru].

Samburg A.L., 1971. Geological Map of the USSR, scale 1:200000. East Sayan Series (Explanatory Note). Sheet M-48-I. Moscow, 89 p. (in Russian) [Самбург А.Л. Геологическая карта СССР масштаба 1:200000. Серия ВосточноСаянская (объяснительная записка). Лист М-48-I. М., 1971. 89 с.].

Smekalin O.P., 2000. Paleoearthquakes in the Tunka system of rift basins. Synopsis of the thesis for Candidate of Geology and Mineralogy degree. Irkutsk. 29 p. (in Russian) [Смекалин О.П. Палеоземлетрясения в тункинской системе рифтовых впадин: Автореф. дис. ... канд. геол.-мин. наук. Иркутск, 2000. 29 с.].

Solonenko V.P. (Ed.), 1963. Mudflow Flooding in Slyudyanka at Lake Baikal on 20 June 1960. Publishing House of the USSR Acad. Sci., Moscow, 72 p. (in Russian) [Селевой паводок в г. Слюдянке на Байкале 20 июня 1960 г. / Отв. ред. В.П. Солоненко. М.: АН СССР, 1963. 72 с.].

Vasilievsky M.M., Tolstikhin N.I., 1930. Arshan-Tunka mineral spring. In: Materials on geology and mineral deposits of East Siberia. Issue 2. Irkutsk, p. 1-35 (in Russian) [Васильевский М.М., Толстихин Н.И. Минеральный источник АршанТункинский // Материалы по геологии и полезным ископаемым Восточной Сибири. Иркутск, 1930. Вып. 2. С. 1 35]. 


\section{ПРИЛОЖЕНИЕ / APPENDIX}

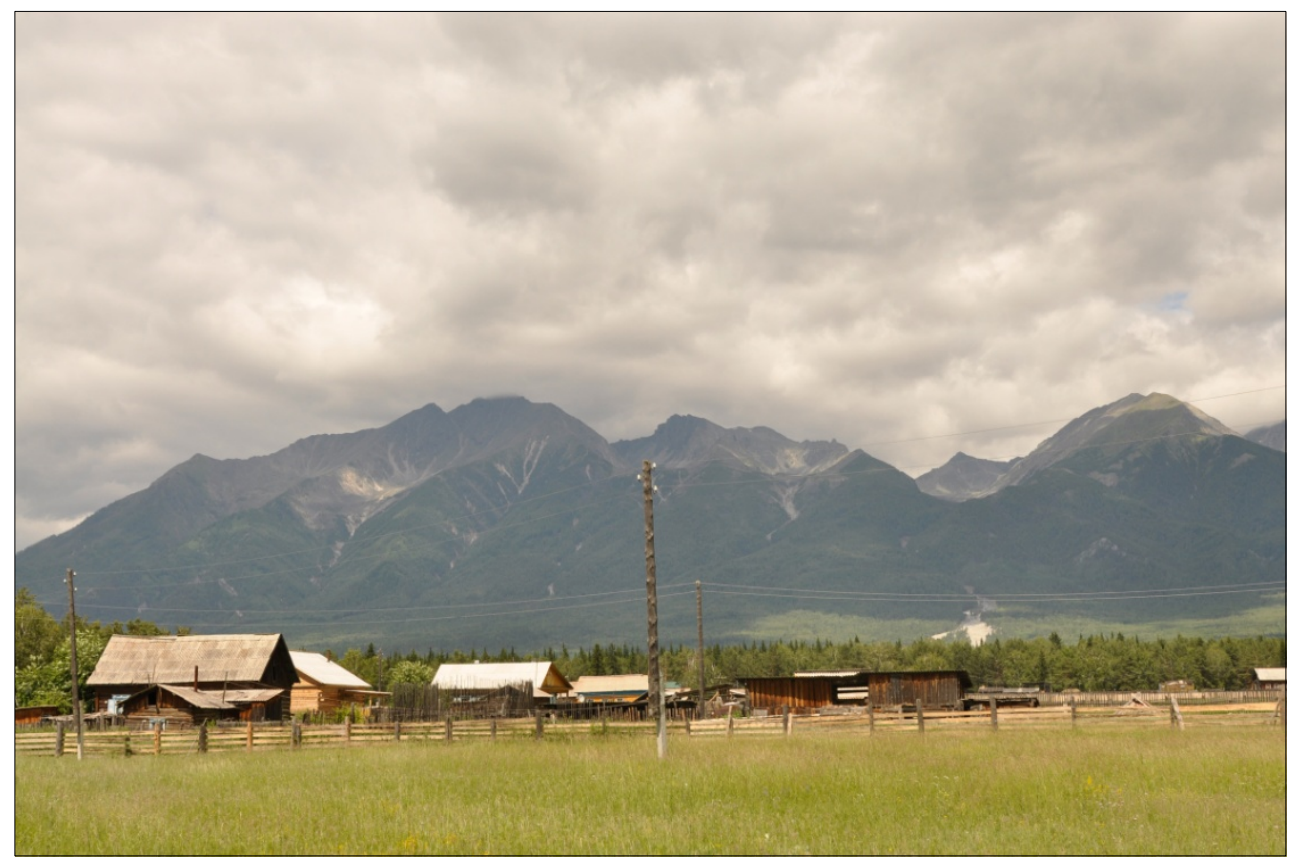

Фото 1. Общий вид Тункинских Гольцов - места формирования и схода селей, следы которых на фоне гор выделяются светлыми пятнами промоин, прочесов, оползней-сплывов и их отложений.

Photo 1. A general view of Tunka Goltsy. At the background of mountains, lighter spots are washed and 'mopped' areas, landslips, landslides and deposits.

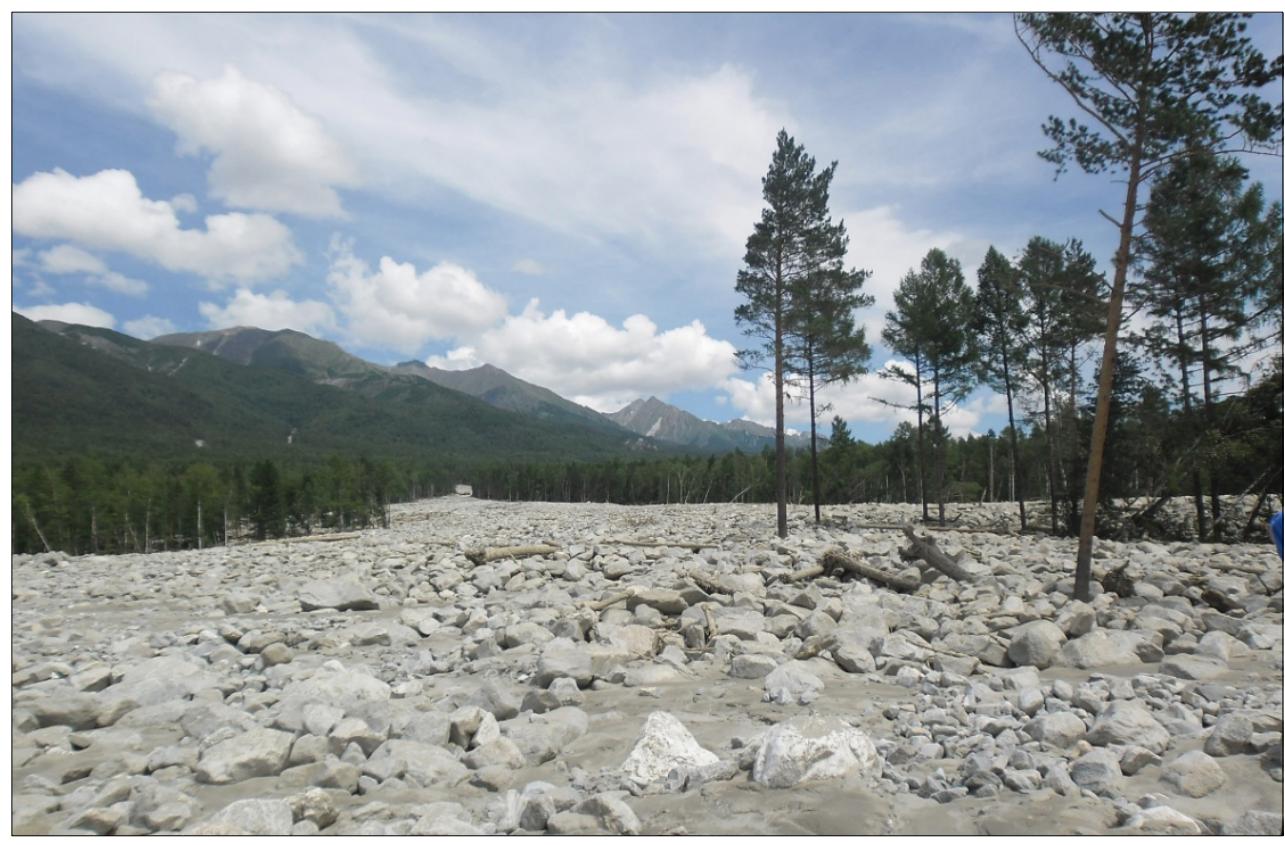

Фото 2. Грязекаменная масса на пути движения уничтожила сосновый бор, выполнявший сдерживающую роль и послуживший одной из основных причин остановки селевого потока. Оставшиеся островки леса, выдержавшие натиск стихии, станут природными памятниками борьбы за выживание.

Photo 2. The mud-and-stone flow destroyed the pine forest. It was slowed down and stopped mainly due to resistance of the forest. The remaining forested spots that sustained the disaster will become natural symbols of the struggle for survival. 

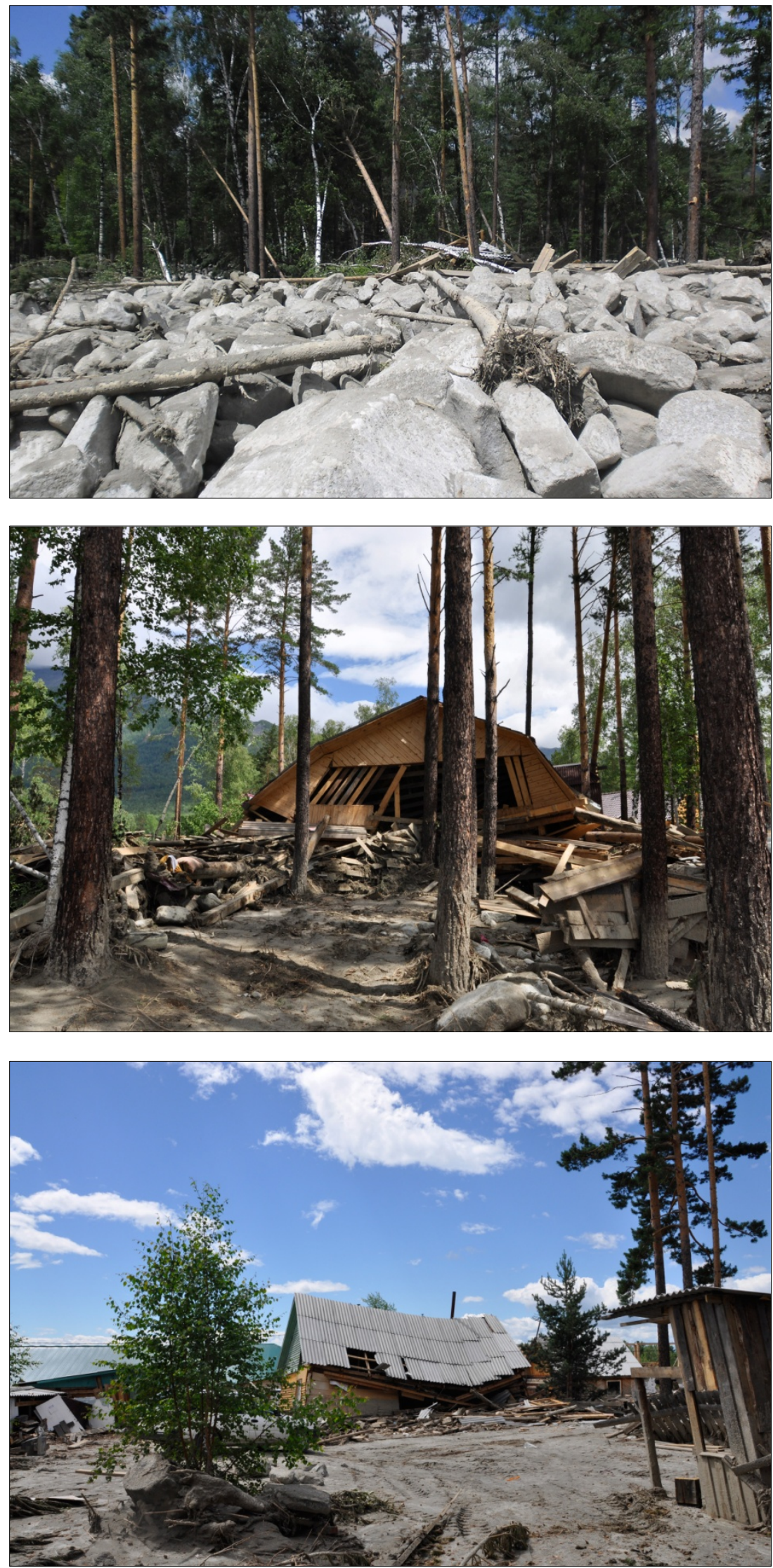

Фото 3-1. Фото 3-2. Фото 3-3. Грязекаменный поток похоронил часть домов на окраине поселка, а другую разрушил и, встретив лесной массив, потерял скорость и остановился.

Photo 3-1. Photo 3-2. Photo 3-3. The mud-and-stone flow buried and damaged several houses located at the outskirts of the village; its movement was slowed down and suspended by the forest. 

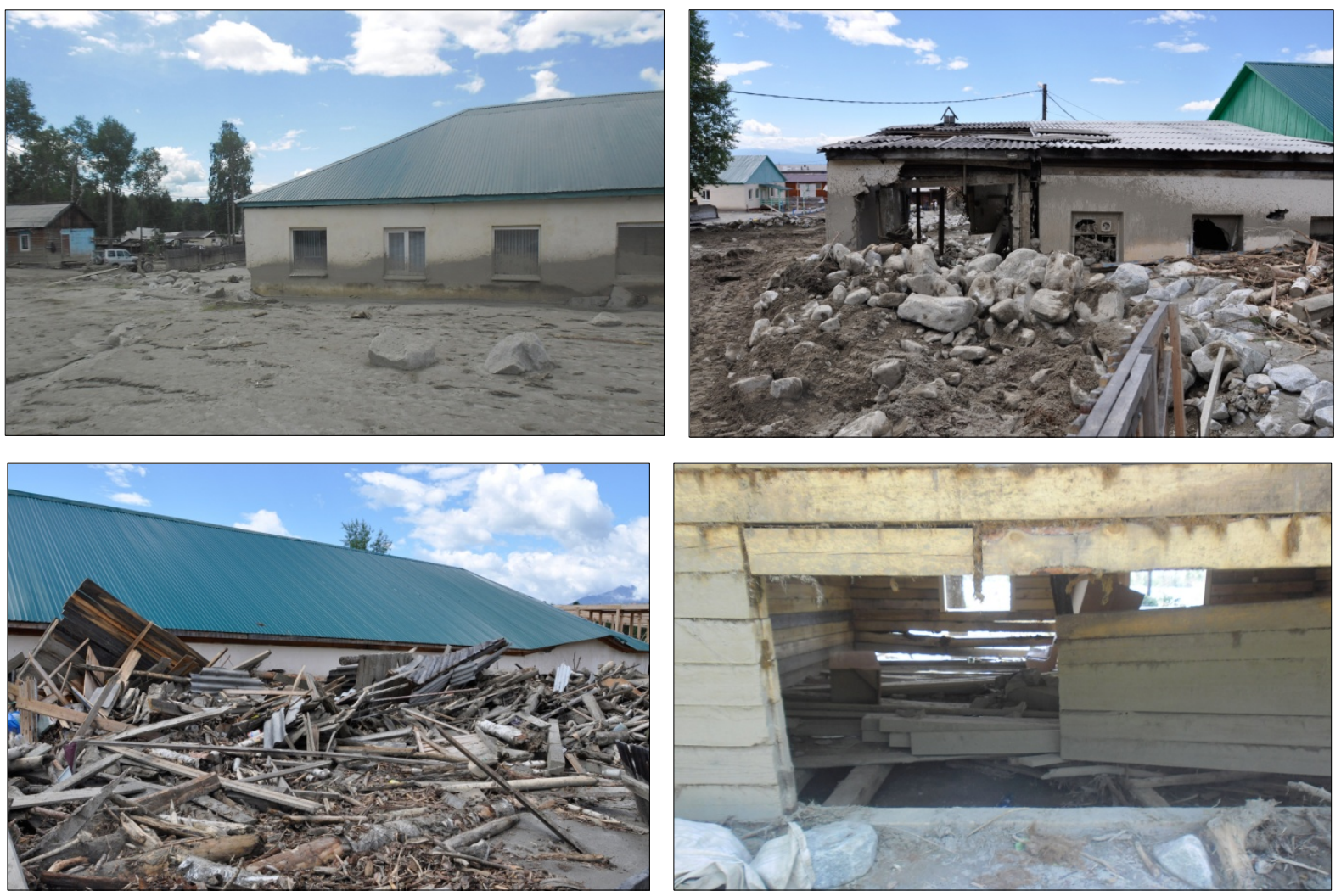

Фото 4-1. Фото 4-2. Фото 4-3. Фото 4-4. Хвостовая часть селевого потока продолжала двигаться, и это стало причиной поворота движения грязекаменных масс в сторону пос. Аршан.

Photo 4-1. Photo 4-2. Photo 4-3. Photo 4-4. As the tail of the mudflow moved further, the flow containing mud, stones and demolition debris turned towards the Arshan village.

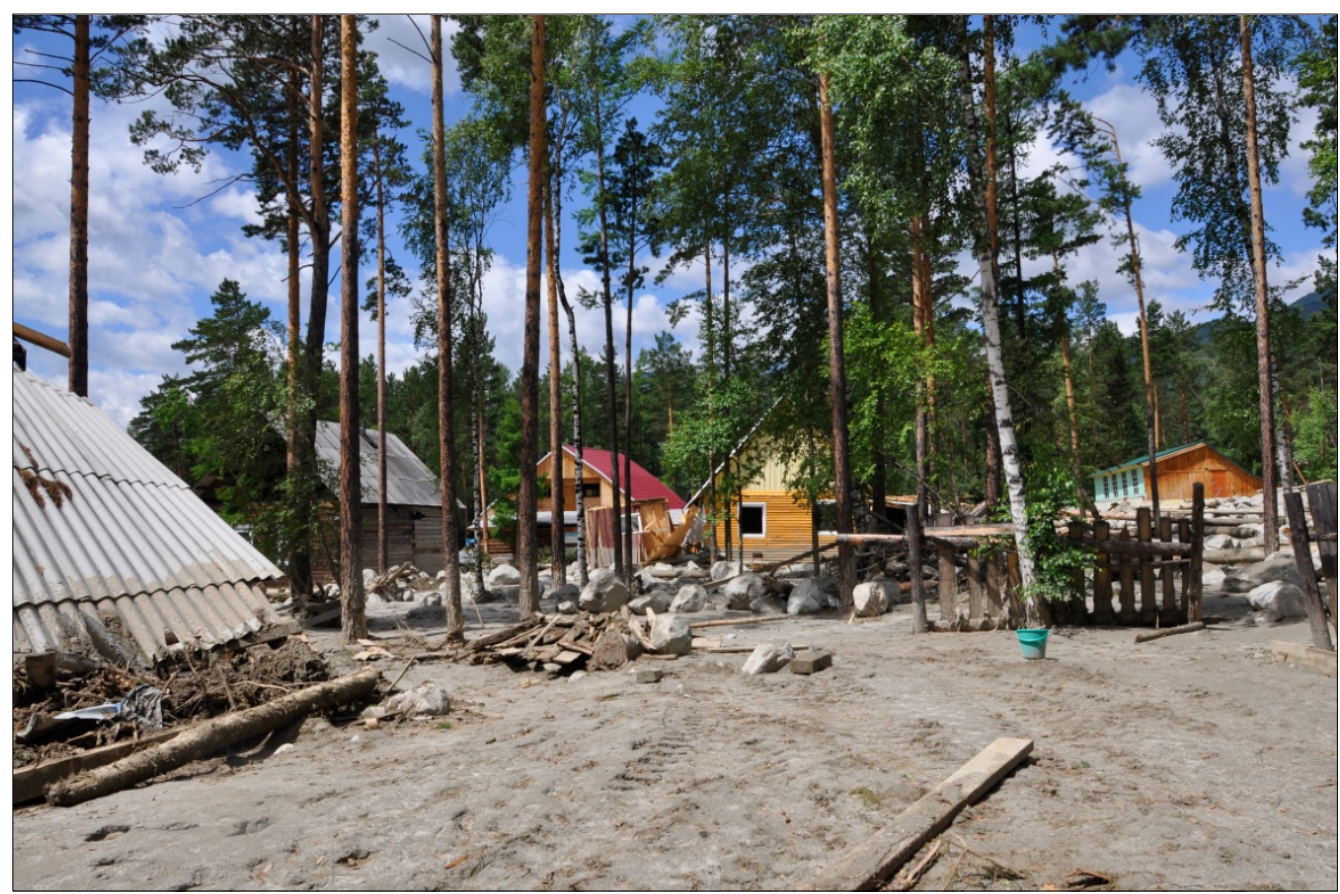

Фото 5. Лес, отфильтровав грязекаменную массу, спас дома от разрушения.

I Photo 5. The forest 'filtered' the mud-and-stone mix and thus rescued the house from demolition. 

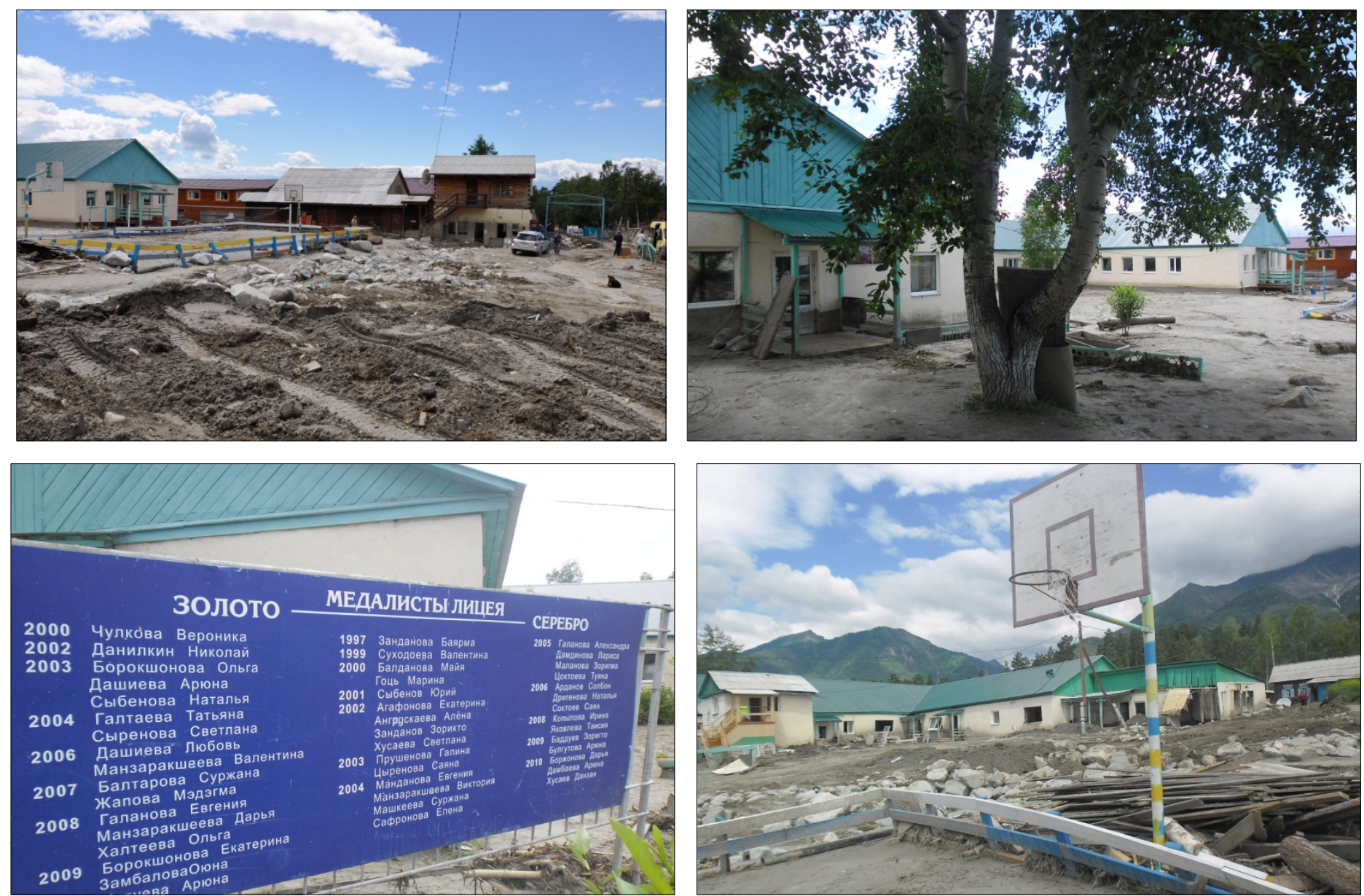

Фото 6-1. Фото 6-2. Фото 6-3. Фото 6-4. Характер повреждений хозяйства лицея для одаренных детей.

| Photo 6-1. Photo 6-2. Photo 6-3. Photo 6-4. Damaged facilities of the Gifted Children School.
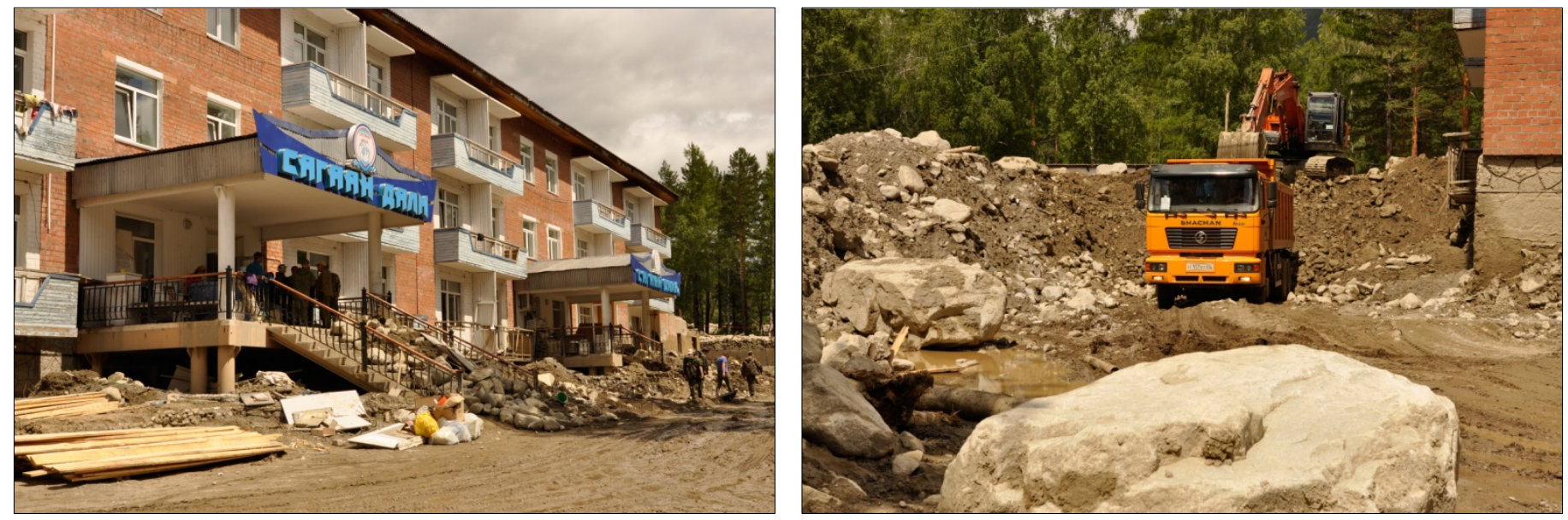

Фото 7-1. Фото 7-2. Гостиничный комплекс «Сагаан Дали» - расчистка первого этажа корпуса от валунов и грязи выполняется волонтерами. Основную селевую массу убирает тяжелая техника.

Photo 7-1. Photo 7-2. Volunteers are cleaning the ground floor of Sagaan Dali Hotel from mud and stones. Heavy machinery is used to clear the area from mudflow deposits. 

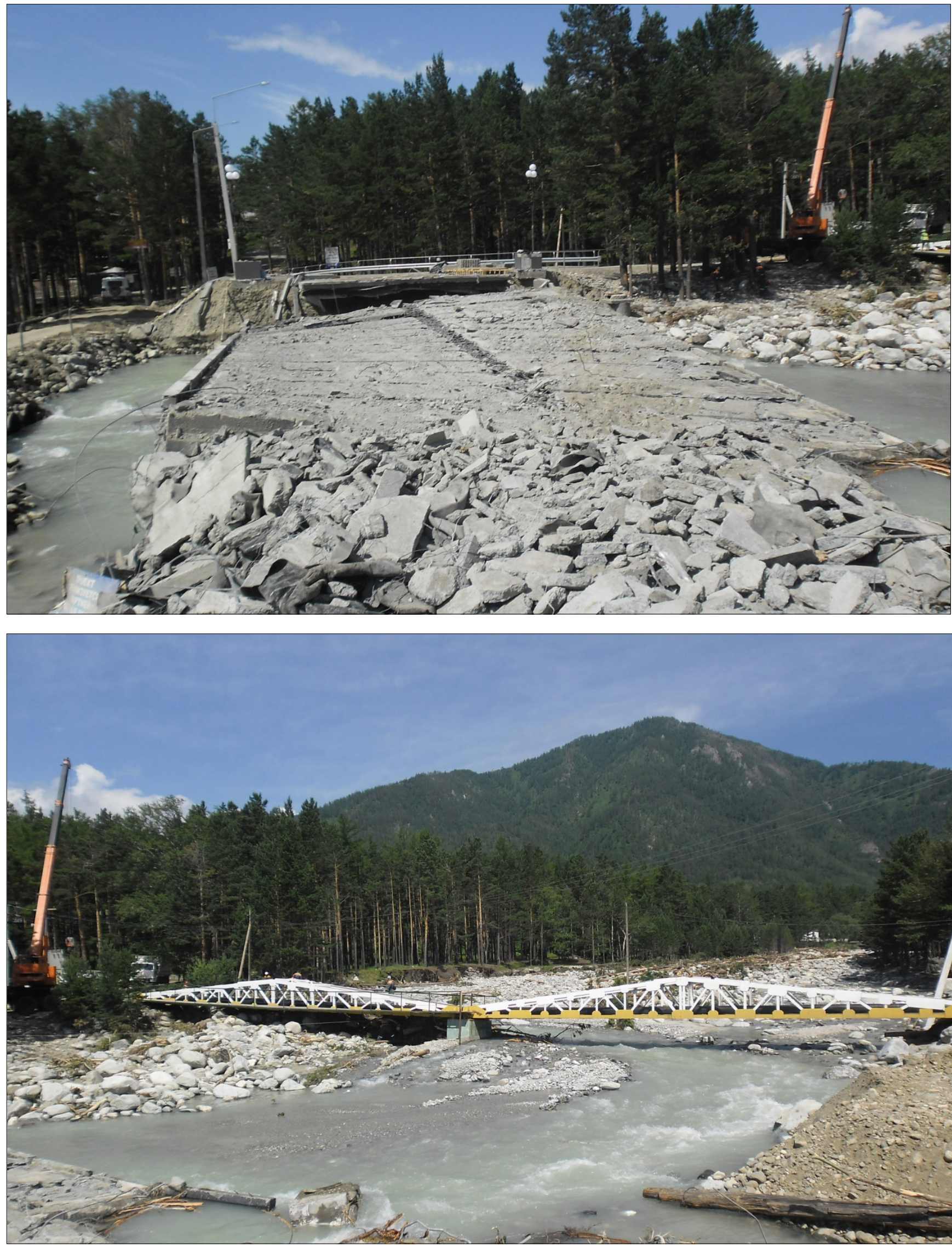

| Фото 8-1. Фото 8-2. Паводок на р. Кынгарге повредил мосты.

Photo 8-1. Photo 8-2. Bridges damaged by the Kyngarga river flood. 

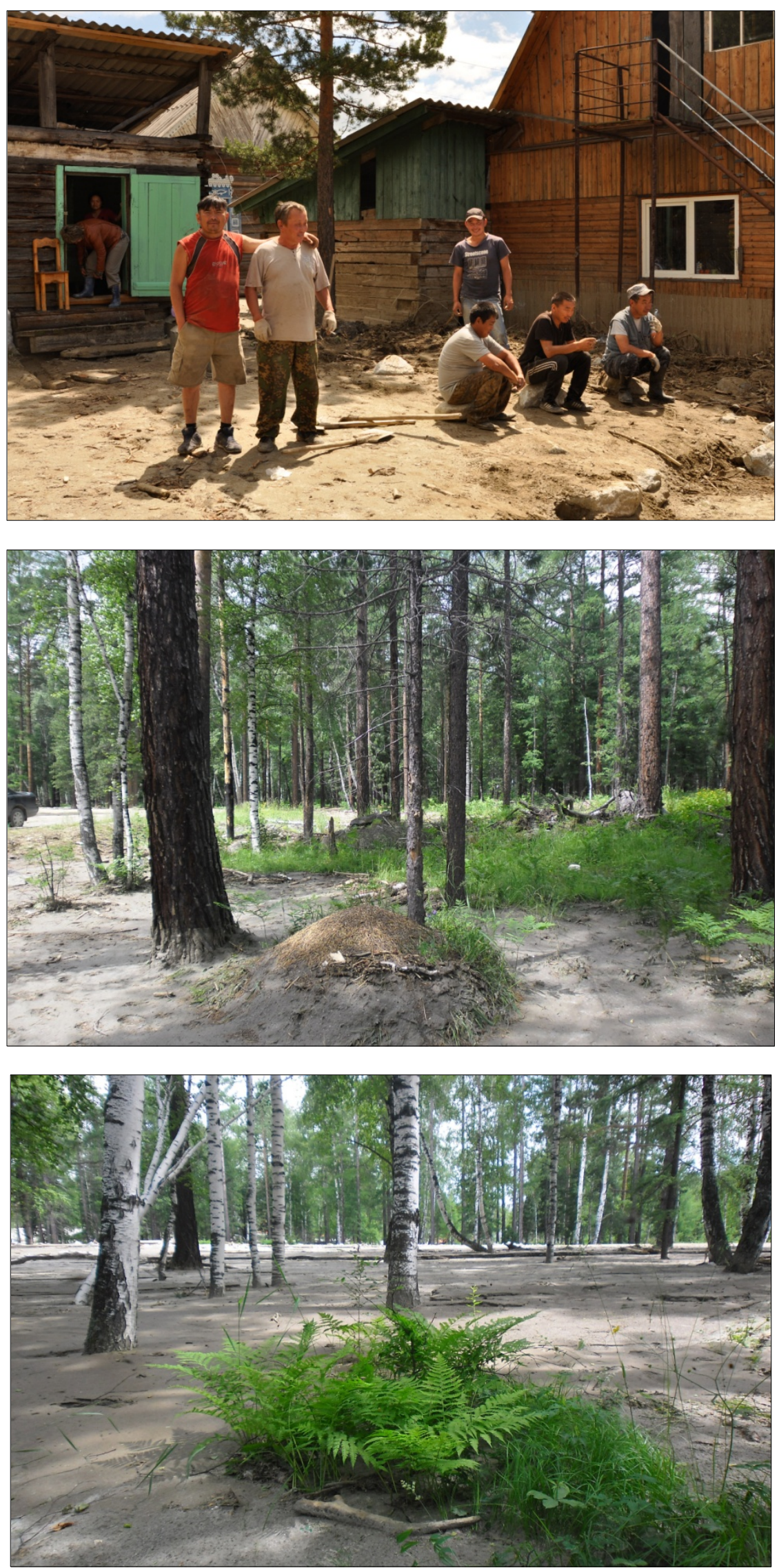

| Фото 9-1. Фото 9-2. Фото 9-3. Сели прошли, а жизнь продолжается.

| Photo 9-1. Photo 9-2. Photo 9-3. Mud flowing is over, and life goes on. 

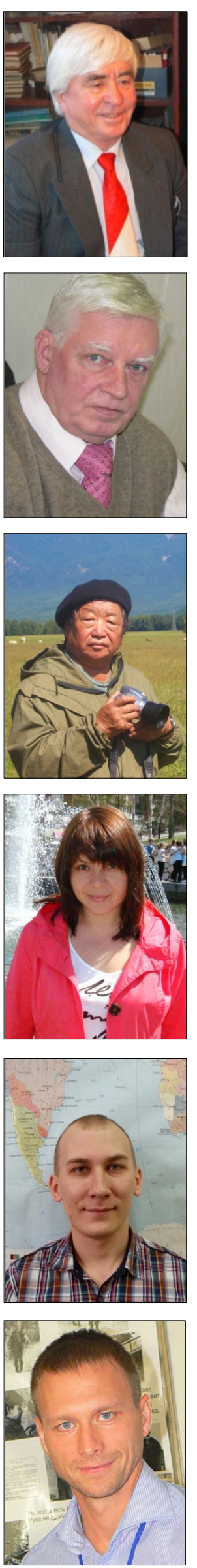

Лапердин Валерий Кириллович, докт. геол.-мин. наук, с.н.с.

Институт земной коры СО РАН

664033, Иркутск, ул. Лермонтова, 128, Россия

\ e-mail: laperdin@crust.irk.ru

Laperdin, Valery K., Doctor of Geology and Mineralogy, Senior Researcher Institute of the Earth's Crust of SB RAS

128 Lermontov street, Irkutsk 664033, Russia

凶 e-mail: laperdin@crust.irk.ru

Леви Кирилл Георгиевич, докт. геол.-мин. наук, профессор, зам. директора института по науке Институт земной коры СО РАН

664033, Иркутск, ул. Лермонтова, 128, Россия

Тел. (3952)424562; email: levi@crust.irk.ru

Levi, Kirill G., Doctor of Geology and Mineralogy, Professor, Deputy Director

Institute of the Earth's Crust of SB RAS

128 Lermontov street, Irkutsk 664033, Russia

Tel. +7(3952)424562; email: levi@crust.irk.ru

Лехатинов Анатолий Михайлович, докт. геол.-мин. наук

Институт земной коры СО РАН

664033, Иркутск, ул. Лермонтова, 128, Россия

Lekhatinov, Anatoly M., Doctor of Geology and Mineralogy

Institute of the Earth's Crust of SB RAS

128 Lermontov street, Irkutsk 664033, Russia

Кадетова Алена Васильевна, канд. геол.-мин. наук, н.с.

Институт земной коры СО РАН

664033, Иркутск, ул. Лермонтова, 128, Россия

e-mail: kadetova@crust.irk.ru

Kadetova, Alena V., Candidate of Geology and Mineralogy, Researcher

Institute of the Earth's Crust of SB RAS

128 Lermontov street, Irkutsk 664033, Russia

e-mail: kadetova@crust.irk.ru

Пеллинен Вадим А., старший лаборант-исследователь

Институт земной коры СО РАН

664033, Иркутск, ул. Лермонтова, 128, Россия

e-mail: pellinen@crust.irk.ru

Pellinen, Vadim A., Senior laboratory assistant Institute of the Earth's Crust of SB RAS

128 Lermontov street, Irkutsk 664033, Russia

e-mail: pellinen@crust.irk.ru

Рыбченко Артем Александрович, канд. геол.-мин. наук, с.н.с.

Институт земной коры СО РАН

664033, Иркутск, ул. Лермонтова, 128, Россия

e-mail: rybchenk@crust.irk.ru

Rybchenko, Artem A., Candidate of Geology and Mineralogy, Senior Researcher Institute of the Earth's Crust of SB RAS

128 Lermontov street, Irkutsk 664033, Russia

e-mail: rybchenk@crust.irk.ru 